\title{
The coagulating gland in the male greater cane rat (Thryonomys swinderianus): morphological and immunohistochemical features
}

\author{
A.O. Adebayo ${ }^{1,2,3}$, A.K. Akinloye2 , A.O. Ihunwo ${ }^{3}$, B.O. Oke ${ }^{1}$ \\ ${ }^{1}$ Department of Veterinary Anatomy, Faculty of Veterinary Medicine, University of Ibadan, Nigeria \\ ${ }^{2}$ Department of Veterinary Anatomy, College of Veterinary Medicine, Federal University of Agriculture, \\ Abeokuta, Nigeria \\ ${ }^{3}$ School of Anatomical Sciences, Faculty of Health Sciences, University of the Witwatersrand, Johannesburg, \\ South Africa
}

[Received 26 February 2014; Accepted 22 April 2014]

This study reveals the structure, ultrastructure and immunoexpression of oestrogen alpha and beta receptors ( $E R \alpha$ and $E R \beta$ ) in the coagulating glands of the greater cane rat. Gland samples from 15 adult male cane rats were processed for histological and ultrastructural studies while immunohistochemistry was also carried out. Coagulating gland in the cane rat is a paired, triangularly shaped, transparent gland weighing about $1 \pm 0.48 \mathrm{~g}$. Histologically, each secretory acinus is composed of folded mucosa surrounded by fibromuscular stroma. The simple columnar epithelium consists of principal cells at different stages of secretion evidenced by their apical blebs of various heights and occasional basal cells. Fine structure of the principal cells revealed the presence of apical blebs that contained secretory granules of varying electron-density, secretory vesicles and vacuoles on both their luminal surfaces and the lumen. While supranuclear cytoplasm contained Golgi apparatus with different cisternal arrangements, the infranuclear part is covered with dilated rough endoplasmic reticulum cisternae. Nuclei, apical bleb and stroma of secretory epithelium all showed positive immunostaining for $E R \alpha$ and $E R \beta$. These findings revealed the prominence of apocrine secretion with no structural evidence of merocrine secretion and the uncommon $E R \alpha$ and $E R \beta$ distribution pattern in the coagulating gland of the cane rat. (Folia Morphol 2015; 74, 1: 25-32)

Key words: coagulating gland, ultrastructure, greater cane rat, oestrogen receptors

\section{INTRODUCTION}

The coagulating gland is an accessory sex gland found in rodents and monkeys [20,30]. In rodents, the protein and fructose-rich secretions of this gland play a major role in semen coagulation and sperm motility thereby enhancing fertilisation efficacy in these species $[4,10]$. These secretions also, through complex biochemical interactions with secretions from vesicular and bulbourethral glands, form copulatory plugs that prevent semen backflow from the female reproductive tract after coitus $[8,23]$.

The coagulating gland is usually considered to be part of the prostate gland and often referred to as the anterior prostate in rat and mice because of its embryonic origin from the urogenital sinus and the prostatic complex $[9,10]$. Though absent in 
man, this gland in mice has also been reported to be embryologically homologous to the middle lobe and structurally related to the central zone of the human prostate $[15,25]$. It however, shows varying structural diversities that make it a distinct accessory sex gland especially among wild rodents $[12,21]$ and which will possibly impact on its role in the reproduction of each of these wild species.

The development and normal functioning of the coagulating gland, like other accessory glands, depends on androgen mediated through its receptors $[9,12,27]$. Besides androgen, oestrogen has also been reported to play significant roles in the accessory sex glands [11, 19, 24]. According to Ellem and Risbridger [14] although some rapid non-genomic oestrogen signalling are now being identified, the effect of oestrogen on the accessory gland particularly the prostate gland, under normal and prostatic disease conditions are principally mediated via the two oestrogen receptors ( $E R \alpha$ and $\beta$ ). The localisation and the pattern of distribution of these two receptors in tissues such as the prostate gland are the basis for the understanding of their roles under normal or disease conditions $[14,24,26]$. While extensive works have been done on the presence and pattern of expression of these receptors in other accessory glands, little is known about them in the coagulating gland especially in wild rodents that are undergoing domestication.

The greater cane rat (Thryonomys swinderianus) is a wild rodent of the order hystricomorpha found only in Africa where it is vigorously hunted and exploited for food because of its excellent meat taste and high nutritive value [1]. It is currently undergoing domestication and captive rearing in parts of West Africa sub region and the current trend in its farming is towards increased stock levels and intensification of production practices [2].

The structure and ultrastructure of the coagulating gland have been studied in some wild and domestic rodents like mice [7], rat [17], African giant rat [22], and Viscacha [12] but little or no information exist on the morphology of the coagulating gland in the greater cane rat. The purpose of this study therefore, is to describe the morphological features of the coagulating gland at gross, histological and ultrastructural levels as well as analyse the immunohistochemical expression and distribution pattern of the two oestrogen receptors ( $\operatorname{ER} \alpha$ and $\beta$ ) of this gland in the greater cane rat.

\section{MATERIALS AND METHODS}

\section{Animals}

Captive-reared, adult and sexually mature male greater cane rats $(n=15)$, with known reproductive and health records were used in this work. Ten of the animals $(n=10)$ were used for morphological and morphometric studies while $5(n=5)$ were for immunohistochemistry. All the animals were still being used for breeding and were fed commercial cane rat feed and elephant grass with water ad libitum. The experimental protocol and animal handling followed the ethical principles in animal research adopted by the Council on Animal Experimentation of the University of Ibadan, Nigeria.

\section{Gross evaluation and measurements}

Each of the animals was weighed, anaesthetised using chloroform inhalation anaesthesia (Merck, Germany) placed in cotton wool in a closed jar and dissected open after being perfusion-fixed transcardially using the Karnovsky's fixative which is phosphate buffered $2 \%$ paraformaldehyde $-2.5 \%$ glutaraldehyde fixative at pH 7.4 (for morphological studies) and phosphate buffered $4 \%$ paraformaldehyde at $\mathrm{pH} 7.4$ (for immunohistochemistry). After opening the abdominal and pelvic cavities, the pelvic symphysis of each animal was disarticulated to expose the coagulating gland in situ. The gland was then separated and dissected away from the other accessory sex glands. After thorough gross assessment, the organ was weighed (with its secretory content), measured (for volume) and photographed (Samsung Digital camera, S100, Japan).

\section{Histology and histomorphometry}

Histological samples from the coagulating gland were further fixed in Karnovsky's fixative, dehydrated in graded series of ethanol, cleared in xylene and paraffin-embedded. $5 \mu \mathrm{m}$-thick sections were mounted on albumenised slides, stained with $\mathrm{H}$ and $\mathrm{E}$ and examined under Axioskop 2 plus, Carl Zeiss light microscope (Germany). Histomorphometric measurements of luminal diameters, fibromuscular thickness, epithelial heights and fold heights were also carried out on these slides using a photomicroscope (AxioSkop-2-Plus, ZEISS, Germany) with AxioVision Release 4.8.1 software package. Values obtained were expressed in mean \pm standard deviation $(n=10)$ and evaluated with ANOVA using Paleontological statistics version 2.15 (PAST) data analysis tool. 


\section{Electron microscopy}

Ultrastructural studies were carried on the samples after being further immersed in Karnovsky's fixative, postfixed in $1 \%$ osmium tetraoxide for $1 \mathrm{~h}$, dehydrated in an increasing ethanol series, infiltrated and embedded in Epon-Araldide resin. Semithin and ultrathin sections were cut with an Ultracut S ultramicrotome. While the semithin sections were stained with Toluidine blue-Pyronin $\mathrm{Y}$ mixture and examined under the light microscope, the ultrathin sections were mounted on copper grids, double-stained with uranyl acetate and lead citrate and observed in a Phillips CM10 Transmission Electron Microscope (TEM).

\section{Immunohistochemistry}

The immunohistochemical studies of the oestrogen receptors were carried out on $5 \mu \mathrm{m}$ thick coagulating gland tissue sections which were first deparaffinised and rehydrated in decreasing ethanol concentrations. To retrieve the oestrogen ( $\alpha$ and $\beta$ ) antigens, the sections were heated in citrate buffer-Tween 20 solution ( $2.94 \mathrm{~g}$ of Tri-sodium citrate [dehydrate] dissolved in $1000 \mathrm{~mL}$ distilled water at $\mathrm{pH}$ 6.0 plus $0.5 \mathrm{~mL}$ of Tween-20) in a microwave oven (DMO 289 Model, Defy, South Africa) set at $720 \mathrm{~W}$ for $10 \mathrm{~min}$ and thereafter washed thrice in Tris buffered solution (TBS $17.54 \mathrm{~g}$ of $\mathrm{NaCl}$ and $12.12 \mathrm{~g}$ of Tris base; Tris [hydroxymethyl] aminomethane; in $2 \mathrm{~L}$ of distilled water at $\mathrm{pH}$ 7.6). Endogenous peroxidase was inhibited by treating the sections for 30 min with $3 \%$ hydrogen peroxide $\left(\mathrm{H}_{2} \mathrm{O}_{2}\right)$ in methanol obtained from Novocastra $^{\mathrm{TM}}$ kit (Peroxidase Detection System; RE 7110-K, Novocastra, UK) and thereafter washed thrice in TBS. Nonspecific binding sites for immunoglobulins were blocked by incubating sections for $20 \mathrm{~min}$ in pre-constituted protein blocking solution (RE 7102 Novocastra ${ }^{\mathrm{TM}}$ kit). Upon washing in TBS, the sections were incubated overnight at $4^{\circ} \mathrm{C}$ with $1: 100$ dilution of $1 \mu \mathrm{L}$ rabbit polyclonal for oestrogen receptor alpha (ER $\alpha$ - Ab37438, Abcam $^{\circledR}$, UK) and oestrogen receptor beta $\left(\mathrm{ER} \beta\right.$ - Ab3577, $\left.\mathrm{Abcam}^{\circledR}, \mathrm{UK}\right)$ on separately labelled slides. Sections were rinsed in TBS and treated for $30 \mathrm{~min}$ at room temperature with 1:300 dilution of biotinylated goat-anti-rabbit secondary antibody (Vector, USA) made in TBS. Sections were subsequently incubated with Streptavidin-Horse Radish Peroxidase mixture (RE 7104 Novocastra $^{T M}$ kit) for $30 \mathrm{~min}$ at room temperature. The mixture contained $1-1.4 \mu \mathrm{g}$ of Streptavidin-HRP in $1 \mathrm{~mL}$ TBS with protein stabiliser and $0.35 \%$ Pro-Clin ${ }^{\text {TM }}$ 950. Peroxidase
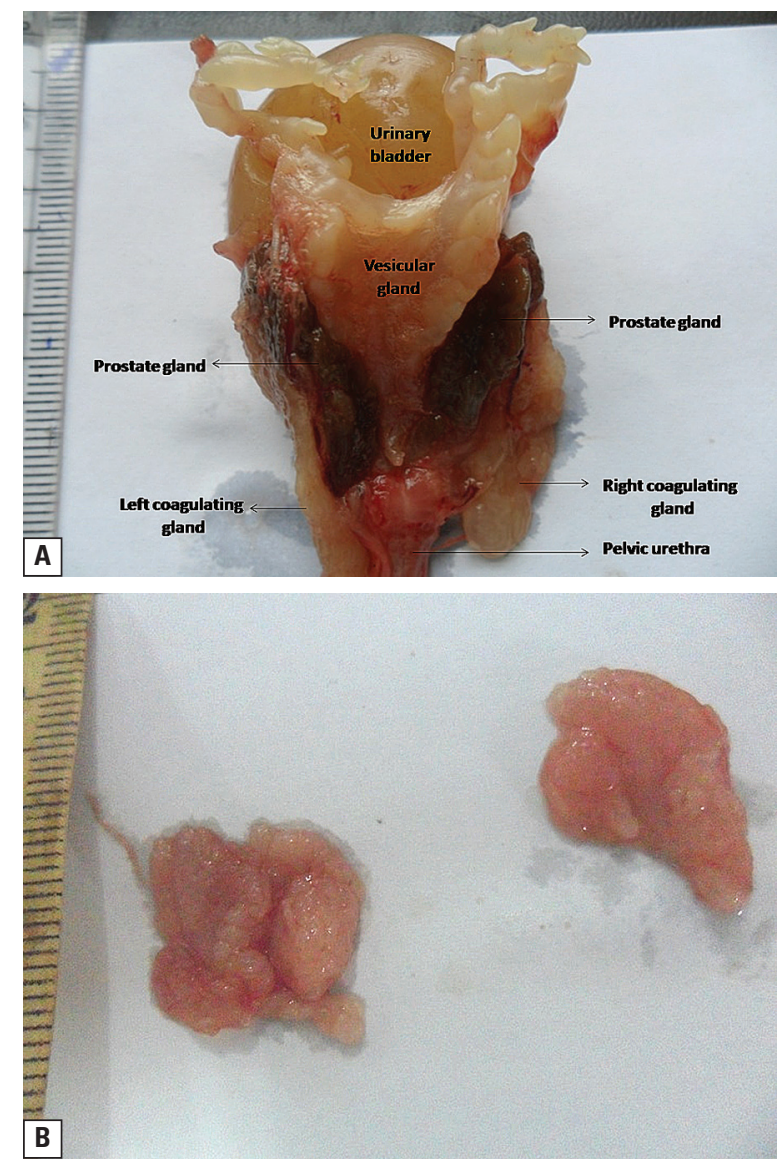

Figure 1. The coagulating gland in the greater cane rat; $\mathbf{A}$. Gland relative to prostate gland, vesicular gland, urinary bladder and the pelvic urethra; $\mathbf{B}$. Isolated coagulating glands.

was developed with $1.74 \%(\mathrm{w} / \mathrm{v})$ 3'3-diaminobenzidine (DAB) and $0.05 \%(v / v) \mathrm{H}_{2} \mathrm{O}_{2}$ in TBS. Finally, the immunostained sections were counterstained with haematoxylin. Negative controls were obtained by incubating additional sections with the TBS in the place of the primary antibody.

\section{RESULTS}

\section{Gross structure and histology}

In the greater cane rat, the coagulating gland is a paired, cream-coloured, transparent gland located at the angle between the vesicular and prostate glands (Fig. 1A). It is situated ventrolateral to the prostate, ventral to the vesicular gland but dorsolateral to the neck of the urinary bladder. Each triangularly shaped gland, located at either side of the midline, weighed $1.0 \pm 0.48 \mathrm{~g}$, measured $0.92 \pm 0.30 \mathrm{~cm}^{3}$ in volume and opens into the pelvic urethra by separate duct (Fig. 1B). 

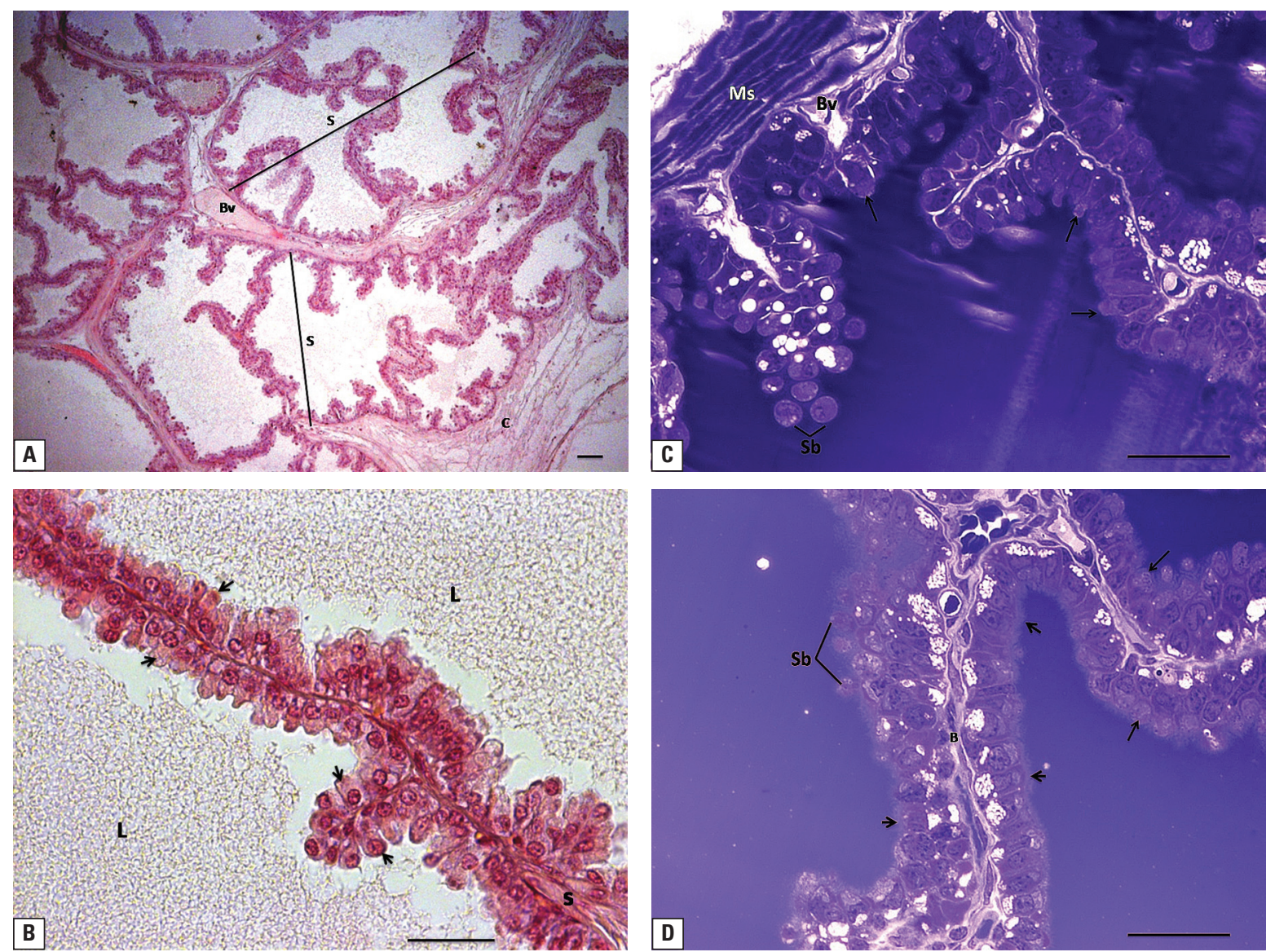

Figure 2. Histology of the coagulating gland of the greater cane rat; $A$. Secretory granules (S), the stromal blood vessels (Bv) and the thin capsule that covers the gland (C); $\mathrm{H}$ and E; scale bar: $50 \mu \mathrm{m}$; B. Mucosal fold that projects into the secretory lumen (L) and consists of the principal cells (arrows) underlain by stromal septum (S); H and E, scale bar: $20 \mu \mathrm{m}$; C. Secretory cells with their apical blebs (arrows) and some of the secreted blebs $(\mathrm{Sb})$ released in the lumen and the stroma muscular layers (Ms); D. Non-secreting cells (short arrows) with microvilli, some secreting cells (long arrows) with their apical blebs and released blebs (Sb) as well as basal cells (B); toluidine blue, scale bar: $20 \mu \mathrm{m}$.

The gland is covered by thin dense irregular capsule which divides the gland into secretory acini (Fig. 2A). Each acinus is made up of folded mucosa surrounded by connective tissue stroma that is $13.98 \pm$ $\pm 0.78 \mu \mathrm{m}$ in thickness and contains smooth muscles and blood vessels (Fig. 2A, C). The glandular mucosa fold with average height of $95.75 \pm 3.50 \mu \mathrm{m}$ is composed of epithelial cells underlie by thin stromal septa that originate for the acini stroma (Fig. 2B, C). The simple columnar epithelium with the height of $12.2 \pm 2.8 \mu \mathrm{m}$, is made up predominantly of principal cells at different stages of secretion intermingled with occasional basal cells (Fig. 2B, C). The apical surfaces of the non-secreting columnar cells are studded with microvilli while the secreting cells have prominent apical blebs of various heights. Each columnar cell nucleus is usually located at the basal
Table 1. Morphometric values of the coagulating gland in the greater cane rat; mean \pm standard deviation

\begin{tabular}{lc}
\hline Body weight $[\mathrm{g}]$ & $2230 \pm 40$ \\
Coagulating gland weight $[\mathrm{g}]$ & $1.0 \pm 0.48$ \\
Coagulating gland volume $\left[\mathrm{cm}^{3}\right]$ & $0.92 \pm 0.30$ \\
Coagulating gland epithelial height $[\mu \mathrm{m}]$ & $12.2 \pm 2.8$ \\
Coagulating gland luminal diameter $[\mu \mathrm{m}]$ & $287.02 \pm 95.2$ \\
Coagulating gland nuclear diameter $[\mu \mathrm{m}]$ & $5.5 \pm 0.72$ \\
Coagulating gland stroma thickness $[\mu \mathrm{m}]$ & $13.98 \pm 0.78$ \\
Coagulating gland fold height $[\mu \mathrm{m}]$ & $95.75 \pm 3.50$ \\
\hline
\end{tabular}

half but often displaced to the centre or apical half by the secretions of the cell. It also has conspicuous nucleolus and measured $5.5 \pm 0.72 \mu \mathrm{m}$ in diameter (Fig. 2C, D, Table 1). 

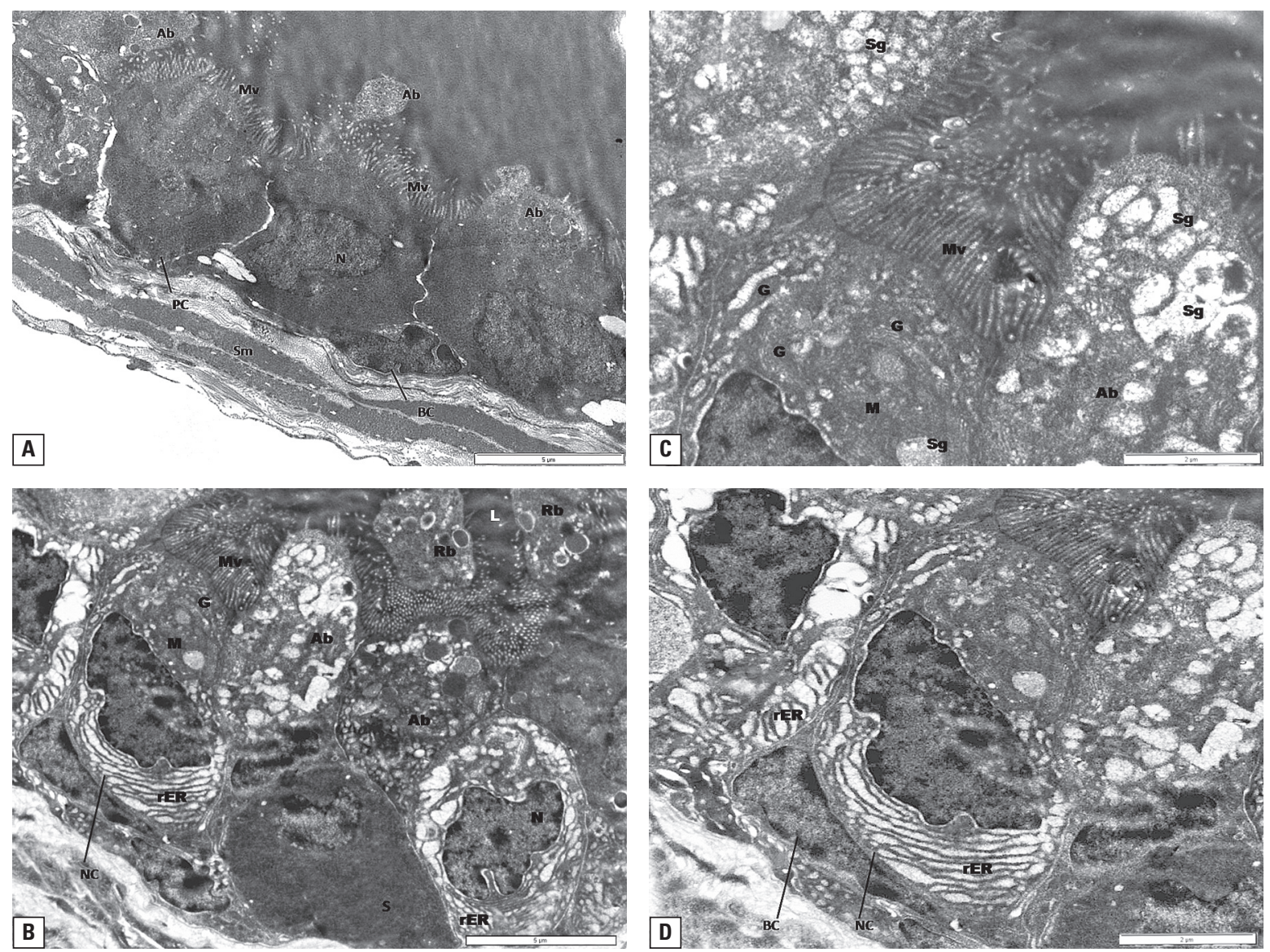

Figure 3. Ultrastructure of the coagulating gland in the greater cane rat. $\mathbf{A}$. The principal $(\mathrm{PC})$ and basal $(\mathrm{BC})$ cells as well as the stromal smooth muscles $(\mathrm{Sm})$. Note the nucleus $(\mathrm{N})$, apical bleb $(\mathrm{Ab})$ at different levels of formation and the microvilli $(\mathrm{Mv})$ on the apical surface of the principal cells; B. Note the prominent microvilli (Mv), Golgi apparatus (G), mitochondria (M), and the rough endoplasmic reticulum (rER) in the non-secreting cells $(\mathrm{NC})$ as well as apical bleb $(\mathrm{Ab})$ on the secreting cells $(\mathrm{S})$ and released blebs $(\mathrm{Rb})$ in the glandular lumen $(\mathrm{L})$; scale bar: $5 \mu \mathrm{m}$; C. Apical cytoplasm of non-secreting principal cell showing the Golgi complexes (G), mitochondria (M), secretory granules $(\mathrm{Sg})$ and microvilli (Mv) as well as the presence of secretory granules of varying electron-density in the apical bleb of secreting cell; $\boldsymbol{D}$. Dilated cisternae of rER at the basal part of the non-secreting cells (NC). The basal cells (BC) have scanty organelles; scale bar: $2 \mu \mathrm{m}$.

\section{Ultrastructure}

The secretory columnar cells of the coagulating gland in the greater cane rat exhibit some peculiar variation in their fine structural appearances and the blebbing of the apical part. Generally, the apical surfaces of the cells are covered with abundant microvilli but cells forming blebs have relatively scanty microvilli depending on the stage of their bleb formation (Fig. 3A, B). However, once the bleb is released into the glandular lumen, the microvilli are fully restored (Fig. 3A). The apical bleb contains numerous secretory granules and secretory vesicles. While some of the secretory granules showed electro-lucent matrix with granular and homogenous contents, others were seen to have dense inclusions of varying sizes (Fig. 3B, C). The secretory vesicles are smaller than the granules and the entire bleb cytoplasm appears granular (Fig. 3C).
At secretion the bleb together with its contents and membrane pinches off from the cell into the lumen (Fig. 3A, B).

The apical cytoplasm of the cells before the formation of the bleb contains abundant Golgi apparatus with both dilated and flattened profiles some of which are arranged in straight or curved pattern. Secretory granules at different stages of development were also observed close to the Golgi cisternae (Fig. 3B, C). The supranuclear cytoplasmic matrix, which contains few mitochondria, is relatively more than that at the basal part (Fig. 3C).

The irregularly shaped nuclei of the secretory columnar cells are euchromatic with heterochromatic patches attached to the nuclear membrane and centrally placed prominent nucleolus (Fig. 3B, D). The basal part of the cell is almost completely filled with 

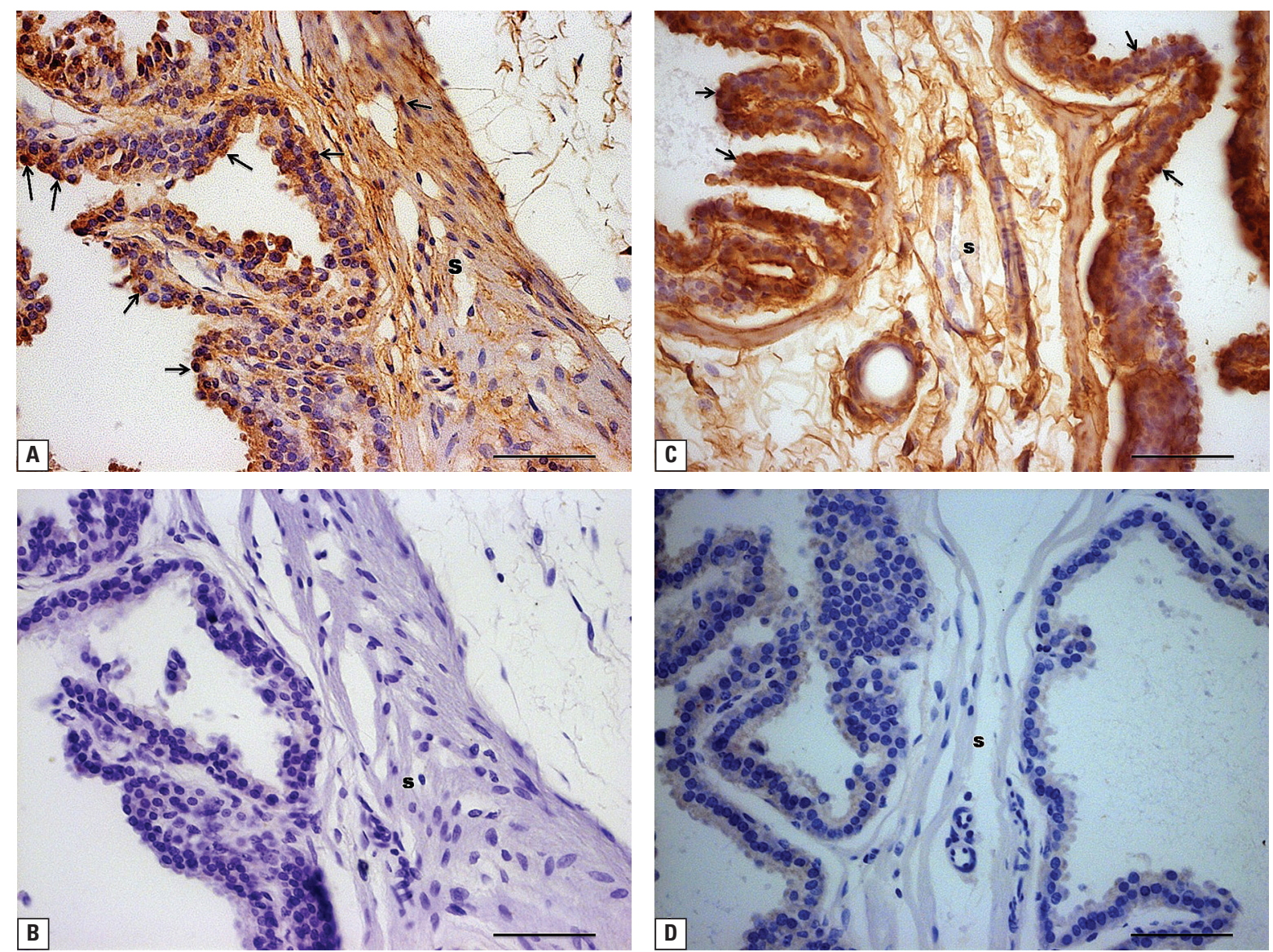

Figure 4. Immunostaining for oestrogen receptors in the coagulating gland in the greater cane rat. A. Positive immunostaining of oestrogen receptor alpha in the columnar cell nuclei and apical blebs (arrows) as well as the stroma (S); B. The negative control; C. Positive immunoexpression for oestrogen beta receptor at the nuclei and apical blebs (arrows) of the glandular epithelium as well as the stroma (S); D. The negative control; scale bar: $A-D=50 \mu \mathrm{m}$.

cisternae of the rough endoplasmic reticulum and numerous secretory vesicles and scanty cytoplasm. The cisternal cavities are dilated with homogenous electron-lucent content (Fig. 3D).

The basal cells are flat with flattened elongated nuclei and scarce cytoplasm. The notched nucleus is euchromatic with patches of heterochromatic clumps but completely lacking nucleolus (Fig. 3A, D). Few organelles are also observed in the scanty cytoplasm.

\section{Oestrogen receptor Immunolabellings}

Positive immunostaining for $\operatorname{ER} \alpha$ and $\operatorname{ER} \beta$ at the glandular epithelium and stroma were observed in the coagulating gland of the cane rat (Fig. 4A, C). The ER $\alpha$ was expressed in the nucleus and the apical bleb of secreting cells as well as the nucleus and surrounding tissues in the stroma (Fig. 4A). There was immunostaining for $E R \beta$ in the nucleus and cytoplasm of the epithelial cells irrespective of their secretory stages and in the surrounding stroma (Fig. 4C).
Figures $4 \mathrm{~B}$ and $4 \mathrm{D}$ are negative controls in the absence of primary antibodies.

\section{DISCUSSION}

The gross features of the coagulating gland in the greater cane rat are unique, being different from that reported in other rodents. In the mouse [9], rat [8] and African giant rat [21], the gland is tubular and lies along almost the entire length of the vesicular glands while in the Viscacha [12], it is located at the upper part of the prostate.

Although the general histological architecture of the coagulating gland in the cane rat is similar to that of other rodents, the pattern of mucosal folding in its secretory acini is unique. The mucosal folding in most rodents $[12,16,21]$ do not traverse the entire lumen of the secretory acini as does occur considerably in the acini of the coagulating gland in the greater cane rat. This structural arrangement may impact on the storage and secretory contribu- 
tions of this gland to the semen and copulatory plug formation in the cane rat.

The observed presence of microvilli on the apical surfaces of the secretory cells was also reported in the mice [9], rat [20] and African giant rat [21]. While it is sparse and small in these rodents, it is large and abundant in the greater cane rat. According to Badia et al. [6] the presence of abundant microvilli and coated vesicles have been associated with absorptive activity in the seminal vesicles. Although the significance of these well-developed microvilli in the coagulating gland of the cane rat is yet to be fully understood, the possibility of an absorptive role cannot be ruled out.

The presence of apical blebs with secretory materials suggest apocrine mode of secretion. According to Aumuller et al. [3], apocrine secretory mechanism is another way of extruding soluble and membrane-bound proteins that are produced in the cytoplasm and intracellularly transported without the involvement of endoplasmic reticulum, Golgi apparatus or the secretory granules. Glands that secrete by apocrine mechanism will normally have cells with apical blebs that contain secretory products and at different stages; some pinching off from the cell and discharged into the lumen and others still attached to the cells with few and scattered microvilli [32]. Although apocrine method of secretion have been described in the coagulating glands of most rodents [15, 21, 32] as well as in other glands in both animals and man $[3,5,6,28]$, this secretion method always coexist with merocrine secretory activities in these glands [6]. The observations in the present study suggest apocrine secretory activities predominate in the coagulating gland of the cane rat.

The observed well-developed Golgi apparatus and rough endoplasmic reticulum with dilated cisternae containing electron-lucent content as well as the presence of secretory granules in the secretory epithelium of the coagulating gland in the cane rat are similar to that reported in most rodents. These features tend to suggest a robust protein synthesis with the packaged secretory products released through the merocrine mechanism [3, 33]. Merocrine secretion is established when the secretory granules are seen bulging or fusing to the apical cell membrane or are present in the luminal content $[6,31]$. From this study however, no structural evidence of merocrine secretion was seen in the coagulating gland.

The presence of basal cells has been reported in the coagulating glands of rodents $[9,20,21]$ but its functional significance is still not clear. In the mouse, where the coagulating gland is considered as the anterior prostate lobe, the basal cells are said to play essential role in the maintenance of normal differentiation of the secretory cells and the integrity of the prostatic ducts [18]. Research work is, however, on-going on the possible roles of the basal cells in the coagulating gland of the greater cane rat.

In this report, we present the immunoexpression of the $\operatorname{ER} \alpha$ and $\operatorname{ER} \beta$ in the coagulating gland of the greater cane rat. Generally, literature on the immunolocalisation of $\operatorname{ER} \alpha$ and $\operatorname{ER} \beta$ in the coagulating gland is scarce since the gland is usually considered as part of the prostate gland in the laboratory animals commonly used for the study of these receptors. The expression of ER $\alpha$ in the nucleus and the apical bleb/ /cytoplasm of the secretory epithelium in the cane rat coagulating gland are unusual. As reported by Prins and Korach [26], ER $\alpha$ is principally localised in the stroma in the prostate gland of rodents, dogs monkeys and humans where it plays a role in the stroma-epithelium interactions of prostate in response to oestrogen. Although the functional significance of the ER $\alpha$ in the secretory epithelium of this gland in the cane rat is still under investigation, epithelial $\mathrm{ER} \alpha$ has been observed in developing human prostate [29] and adult California seal prostate gland [13]. The localisation pattern of $\operatorname{ER} \beta$ in the coagulating gland of the greater cane rat is comparable to what is reported in prostate of rodents [26]. However, further works using other validation techniques are on-going in our laboratory.

\section{CONCLUSIONS}

In conclusion, the structural and ultrastructural peculiarities of the coagulating gland presented in this work, can serve as basis for further research into the role of this gland in the reproductive biology of the greater cane rat.

\section{ACKNOWLEDGEMENTS}

This work was funded by the University of Ibadan Senate Research Grant (No.SRG/FVM/2010/1b) to BOO and partly by the Switzerland-South African Joint Research Programme (SSAJRP) held by AOI. We acknowledge Ms. Pamela Sharp and Hasiena Ali of the University of the Witwatersrand, Johannesburg and Ms. E. van Wilpe of the University of Pretoria, South Africa for their technical assistance. 


\section{REFERENCES}

1. Addo PG, Awumbila B, Awotwi E, Ankrah N-A (2007) Reproductive characteristics of the female grasscutter (Thryonomys swinderianus) and formulation of colony breeding strategies. Livestock Res Rural Development, 15: 1-3.

2. Adu EK, Otsyina RH, Agyei AD (2005) The efficacy of different dose levels of albendazole for reducing fecal worm egg count in naturally infected captive grasscutter (Thryonomys swinderianus, Temminck). Livestock Res Rural Development, 17: 1-6.

3. Aumuller G, Wilhelm B, Seitz J (1999) Apocrine secretion: fact or artifact? Anat Anz, 181: 437-446.

4. Aumuller G, Seitz J (1990) Protein secretion and secretory proccess in male accessory sex gland. Int Rev Cytol, 121: 127-231.

5. Baccari GC, Chieffi G, Di Matteo L, Dafnis D, De Rienzo G, Minucci S (2000) Morphology of the Harderian gland of the Gecko, Tarentola mauritanica. J Morphol, 244: 137-142.

6. Badia E, Briz MD, Pinart E, Sancho S, Garcia N, Bassols J, Pruneda A, Bussalleu E, Yeste M, Casas I, Bonet S (2006) Structural and ultrastructural features of boar bulbourethral glands. Tissue Cell, 38: 7-18.

7. Brandes D, Portela A (1960) The fine structure of the epithelial cells of the mouse prostate. II.Ventral lobe epithelium. J Biophysical Biochemical Cytol, 7: 511-514.

8. Carballada R, Esponda P (1992) Role of fluid from seminal vesicles and coagulating glands in sperm transport into the uterus and fertility in rats. J Reprod Fertil, 95: 639-648.

9. Carvalho CAF, Camargo AM, Cagnon VHA, Padovani CR (2003) Effects of experimental diabetes on the structure and ultrastructure of the coagulating gland of C57BL/6J and NOD mice. Anat Rec, 270A: 129-136.

10. Cavazos $F$ (1975) Fine structure and functional correlates of male accessory sex gland of rodents. Am Physiol Soc, 5: 353-380.

11. Chaves EM, Aguilera-merlo C, Cruceno A, Fogal T, Piezzi R, Scardapane L, Dominguez S (2012) Seasonal morphological variations and age-related changes of the seminal vesicle of Viscacha (Lagostomus maximus maximus): an ultrastructural and immunohistochemical study. Anat Rec, 295: 886-895.

12. Chaves EM, Aguilera-Merlo C, Filippa V, Mohamed F, Dominguez S, Scardapane L (2011) Anatomical, histological and immunohistochemical study of the reproductive system accessory glands in male Viscacha (Lagostomus maximus maximus). Anat Histol. Embryol, 40: 11-20.

13. Colegrove KM, Gulland FMD, Naydan DK, Lowenstine $\sqcup$ (2009) Normal morphology and hormone receptor expression in the male California sea lion (Zalophus californianus) genital tract. Anat Rec (Hoboken), 292: 1818-1826.

14. Ellem SJ, Risbridger GP (2009) The dual, opposing roles of estrogen in the prostate. Steroid Enzymes Cancer, 115: 174-186.

15. Groos S, Wilhelm B, Renneberg H, Riva A, Reichelt R, Seitz J, Aumuller G (1999) Simultaneous apocrine and merocrine secretion in the rat coagulating gland. Cell Tissue Res, 295: 495-504.
16. Harmelin A, Danon T, Kela I, Brenner O (2005) Biopsy of the mouse prostate. Laboratory Animals, 39: 215-220.

17. Hawkins WE, Geuze JJ (1977) Secretion in the rat coagulating gland (Anterior prostate) after copulation. Cell Tiss Res, 181: 519-529.

18. Kurita T, Medina RT, Mills AA, Cunha GR (2004) Roles of p63 and basal cells in prostate. Development, 131: 4955-4964.

19. Lazari MFM, Lucas TFG, Yasuhara F, Gomes GRO, Siu ER, Royer C, Sheilla AFF, Porto CS (2009) Estrogen receptors and function in the male reproductive system. Arq Bras Endocrinol Metab, 53: 923-933.

20. Melo SR, Melo-Jr, W, Garcia PJ, Cagnon VHA (1997) UItrastructural study of the coagulating gland epithelium of the rat (rattus norvegicus) after vasectomy. Rev Chil Anat, 15: 159-163.

21. Oke BO, Aire TA (1996) The coagulating gland of the African giant rat (Cricetomys gambianus Waterhouse). Tropical Vet, 14: 23-29.

22. Oke BO (1988) Some aspects of the reproductive biology of the male African giant rat (Cricetomys gambianus, Waterhouse). Ph.D. Thesis, University of Ibadan.

23. Parr MB, de Franca LR, Kepple L, Ying L, Parr EL, Russel LD (1994) The urethral glands of male mice in relation to depletion of secretory granules upon mating. J Reproduction Fertility, 101: 675-680.

24. Pelletier G, Labrie C, Labrie F (2000) Localization of oestrogen receptor alpha, oestrogen receptor beta and androgen receptors in the rat reproductive organs. J Endocrinol, 165: 359-370.

25. Price D (1963) Comparative aspects of development and structure in the prostate. $\mathrm{NCl}$ Monograph, 12: 1-27.

26. Prins GS, Korach KS (2008) The role of estrogens and estrogen receptors in normal prostate growth and disease. Steroids, 73: 233-244.

27. Rennie PS, Bouffard R, Bruchovsky N, Cheng H. (1984) Increased activity of plasminogen activators during involution of the rat ventral prostate. Biochem J, 221: 171-178.

28. Satoh Y, Ishikawa K, Oomori Y, Takede S, Ono K (1992) Secretion mode of the harderian gland of rats after stimulation by cholinergic secretagogues. Acta Anat (Basel), 143: 7-13.

29. Shapiro E, Huang H, Masch RJ, McFadden DE, Wilson EL, Wu XR (2005) Immunolocalization of estrogen receptor alpha and beta in human fetal prostate. J Urol, 174: 2051-2053.

30. Sjostrand NO (1965) The adrenergic innervation of the vas deferens and the accessory male genital gland. Acta Physiol Scand, 169-175.

31. Sluczanowska-Glabowska S, Laszczyńska M, Wylot M, Glabowski W, Piasecka M, Gacarzewicz D (2010) Morphological and immunohistochemical compare of three rat prostate lobe (lateral, dorsal and ventral) in experimental hyperprolactinemia. Folia Histochem Cytobiol, 48: 447-454.

32. Wong YC, Tse MK (1981) Fine structural and functional study of the prostate complex in the guinea pig. Acta Anat, 109: 289-312.

33. Zaviacic M, Jakubovska V, Belosovic M, Breza J (2000) Ultrastructure of the normal adult human female prostate gland (Skene's gland). Anat Embryol (Berl), 201: 51-61. 